\title{
Made in China, financed in Hong Kong
}

\section{Anne-Laure Delatte et Maud Savary-Mornet}

\section{OpenEdition}

\section{Journals}

Édition électronique

URL : http://journals.openedition.org/chinaperspectives/1703

DOI : 10.4000/chinaperspectives. 1703

ISSN : 1996-4617

\section{Éditeur}

Centre d'étude français sur la Chine contemporaine

\section{Édition imprimée}

Date de publication : 15 avril 2007

ISSN : 2070-3449

\section{Référence électronique}

Anne-Laure Delatte et Maud Savary-Mornet, « Made in China, financed in Hong Kong », China Perspectives [En ligne], 2007/2 | 2007, mis en ligne le 08 avril 2008, consulté le 28 octobre 2019. URL: http://journals.openedition.org/chinaperspectives/1703; DOI : 10.4000/chinaperspectives.1703

(C) All rights reserved 
(1)

\title{
Made In China, Financed
}

\section{In Hong Kong}

\author{
ANNE-LAURE DELATTE \\ AND MAUD SAVARY-MORNET
}

\begin{abstract}
Later, I saw the outside world, and I began to wonder how it could be that the English, who were foreigners, were able to achieve what they had achieved over 70 or 80 years with the sterile rock of Hong Kong, while China had produced nothing to equal it in 4,000 years... We must draw inspiration from the English and transpose their example of good government into every region of China.

Sun Yat-sen, addressing students of the University of Hong Kong, 1923
\end{abstract}

W here are we in economic terms ten years after Hong Kong returned to China? This article aims to show that since 1997 economic integration between the Hong Kong SAR and the People's Republic of China has entered a new phase. Despite fundamental differences, the two economies are more closely linked than ever. The SAR has sought to affirm its identity by seeking to adapt itself in the best possible way to the needs of the Chinese economy. All the same, this relationship, with clearly understood interests, involves macroeconomic risks for both parties.

It was no accident that negotiations for the transfer of Hong Kong's sovereignty to China were undertaken in 1982 under Deng Xiaoping, the father of economic reform. True, the last treaty of 1898 provided for a 99 -year lease over the $\mathrm{New}$ Territories; but the various treaties ceding Hong Kong to the British were never recognised by the nationalists or the Chinese Communists. For the Chinese authorities, 1997 was not therefore an absolutely decisive date in any sense: in their view, sovereignty would be regained quite legitimately "in due course", as they put it ${ }^{(1)}$. The opportune moment presented itself when China moved towards a market economy in 1978: Deng Xiaoping had seen that Hong Kong could provide the logistical support, the skills base, and the liberal capitalist environment that would help him bring about reform. Thus, of the four special economic zones set up in 1980, three were established in Guangdong, a province neighbouring Hong Kong. Exchanges between Hong Kong and Guangdong intensified from 1985 onwards: Hong Kong factories were firstly relocated in the special economic zones and then progressively the Pearl River Delta area. In 1990, total Hong Kong investments represented $80 \%$ of all foreign investment in the Chinese province. The Hong Kong economy experienced an accelerated transformation-instead of an Asian dragon specialising in electronics, it became a service economy ( $90 \%$ of GDP) dedicated to the Chinese economy. Henceforth, the port of Victoria became the entry point for secondary resources imported from Southeast Asia to be transformed into consumer goods in the factories of Guangdong, before being sent back to Hong Kong for export to the rest of the world.

The transformation of Kowloon into a Chinese warehouse and the transfer of Hong Kong capital to the Pearl River Delta had therefore taken place before 1997. This is why there were those who said that the handover facilitated what was already happening but would not involve any major change. The terms of the negotiations between the British and Chinese authorities confirmed this view: Hong Kong kept its economic, monetary and financial autonomy, in other words its capitalist system, its currency, its own economic regime, and outlawed any transfer of fiscal responsibility to China. For Hong Kong residents the fear was rather that, with the opening of the border, corruption might find its way in through Chinese cadres and industry barons looking to make a killing in Hong Kong.

Where are we ten years on? This article seeks to show that economic integration between Hong Kong and the PRC has entered a new phase since 1997. Despite differences in currencies, regulations, institutions and control mechanisms, the two economies have never been so closely linked. This new transformation has been brought about by the financial sector. In short, the SAR has sought to affirm its identity not by pursuing financial and monetary autonomy, guaranteed in any case by the Basic Law, but by seeking to adapt itself as best it can to the needs of the Chinese economy. We pres-

1. Michel Bonnin, "Les zigzags de Pékin" in Jean-Philippe Béja (ed), Hong Kong 1997, Fin de siècle, Fin d'un Monde? Bruxelles, Complexe, 1993, pp. 15-35 
ent a table showing the intermeshing of the Hong Kong and Chinese stock exchange and banking sectors, and try to identify the strategic considerations and the macroeconomic risks involved in these arrangements ${ }^{(2)}$.

We highlight the economic and political factors which have led to China's increasing prominence in Hong Kong's financial affairs since 1997. The transformation of Hong Kong's financial landscape is not a result of directives from Beijing, but of a clear understanding of the interests at stake. On the one hand, Hong Kong's position as a Chinese financial hub has enabled it to progress from having regional to international significance. On the other hand, over this period, the PRC has been in a position, within its own borders, to refine its understanding of market mechanisms and experiment with reforms, at the same time as holding on to its protected financial system?a non-convertible currency, and major restrictions on the circulation of capital. Thus, within the space of ten years, we have seen the emergence of an arrangement of a quite specific kind which makes Chinese capitalism even more unusual: the linking of the financial market of a developed economy to the economy of a developing country.

All the same, the model has its limitations as much for Hong Kong as for China. On the one hand, the acceleration of the reform process in China, linked to commitments to the World Trade Organisation (WTO) in the financial sector, could jeopardise Hong Kong's privileged role under these arrangements. Liberalisation upsets the status quo by reducing Hong Kong's competitive advantage. In addition, the increased importance of China in Hong Kong's financial sector brings with it new risks which could affect Hong Kong as a whole. On the other hand, from China's point of view, using Hong Kong to leverage funds places new constraints on currency exchange arrangements. The system proved sustainable as long as funds raised in Hong Kong by Chinese businesses remained limited. But since stock exchange investments have reached historic levels, the repatriation of these funds weighs heavily on the balance of payments, and increases the pressures for more a flexible currency control system. We will discuss the increased risks at the end of the article.

\section{Hong Kong, the financial heritage}

\section{A sophisticated financial market}

By 1997 the "Chinese miracle" was already largely under way: the rate of growth was stable, the well-established macroeconomic model was supported by an export sector with access to a large and very cheap workforce. As with all emerging countries, a crucial stage of development is then to establish the basis of an efficient financial market capable of allocating household savings to the investment needs of enterprises. But China's financial institutions had a disastrous record, and collusion between the state and the productive sector, an inherent feature of communist systems, made this developmental stage especially difficult. The major characteristics of the Chinese financial system in the 1990s were the dubious credit balances of the banking system as a whole and the "casino-like" nature of Chinese stock markets ${ }^{(3)}$.

It is in this context that, in 1997, China, in taking over Hong Kong inherited a capability that was financially competitive, sophisticated and well regulated. Hong Kong's banking system included 437 credit institutions ${ }^{(4)}$ and offices representing more than forty countries; 76 of the 100 major world banks can be found in Hong Kong. In addition, it is an important currency exchange market, seventh in the world, benefiting from the absence of exchange controls, and is also a major centre for funds management with 195 authorised fund managers, the heaviest concentration in Asia. Hong Kong, which at the time of sovereignty transfer had not yet been affected by the Asian recession, offered a profitable, highly capitalised banking system. By the end of 1996, the number of classified loans was $2.08 \%$ of total loans ${ }^{(5)}$, while, at the same period, in banks in mainland China, the figure was over $40 \%$; in 1997, the international ratio of solvency of credit institutions reached $17.8 \%$, more than double international standards. In all, Hong Kong's financial system displayed a level of maturity and sophistication much greater than that of mainland China, as the president of the Hong Kong body responsible for supervision of financial markets put it somewhat mildly in $1997^{(6)}$ :

China, after all, has only been involved in the mar-

2. An analysis of the informal relations between Hong Kong tycoons and mainland baishu has not resulted in an increase in corruption but would probably reveal the basis of a new political economy that does not work to the benefit of Hong Kong's political system. While recognising that the question of informal economic relations between Hong Kong and Beijing is fundamental to an understanding of the Hong Kong economy, we have chosen not to examine it here because it involves a research programme of a different kind.

3. For a description of the Chinese financial system before the reform process, see, for example, Chapter 2 of Françoise Lemoine, L'Economie chinoise, Paris, La Découverte, 2005, pp. 27-33, and Chapter 3 of OECD (ed), Economic Surveys: China, Paris, OECD, 2005, pp. 137-176.

4. Licensed banks, restricted licence banks, and deposit-taking companies

5. Classified loans reflecting substandard, doubtful loans and losses. Source: statistics of the Hong Kong Monetary Authority.

6. Annual report of the Securities and Futures Commission 1996/1997 
In 2003, several factors affected investors' confidence in Hong Kong. Among them, the SARS epidemic and Beijing's attempt to impose article 23 legislation.

ket economy for less than twenty years. Financial markets on the mainland have been in existence for less than seven years. By the standards of developed countries, China's levels of regulation lack depth, and the legal framework lacks predictability.

\section{A policy of small steps: do not frighten in- ternational investors}

While the political status of the former colony was the subject of tough negotiations between British and Chinese authorities, and while these negotiations resulted in theoretical political autonomy for the people of Hong Kong ${ }^{(7)}$, the agreed legislative framework aimed at preserving the Territory's economic model and at insulating each system from the other (cf. insert 1). In other words, it was a question of not killing the goose that laid the golden eggs!

Thus, at the outset, the mainland authorities took great pains after the transfer of sovereignty to reassure foreign investors about their intentions. So, paradoxically, it was more difficult after 1997 for a Chinese Communist Party cadre to obtain a visa for Hong Kong than it had been before ${ }^{(8)}$. In addition, Jiang Zemin showed a lack of interest in southern China, which he considered too rich and powerful, preferring Shanghai, which he wished to restore to its rightful place. But in 2003 the situation changed: the Hong Kong economy, convalescing after the Asian financial crisis in 1997, was brought to a halt by the SARS epidemic.

It became urgent to find a strategy to restart Hong Kong's economy. The replacement of Jiang by Hu Jintao, secretary general since 2003, provided the political climate for a rapprochement between Beijing and Hong Kong. A bilateral arrangement for a free market between Hong Kong and mainland China, the CEPA ${ }^{(9)}$, was signed in 2003. As well as allowing the free circulation of goods, this arrangement included an important financial provision aimed at giving Hong Kong financial institutions more flexible conditions of access to the Chinese market. This bilateral arrangement thus signalled a clear intention to speed up the economic and financial integration of the two zones, a development which Hong Kong now greeted with enthusiasm. In short, in ten years, China's one-sided interests in Hong Kong have been transformed into mutual interests; the question for Hong Kong no longer being so much to preserve its autonomy and foster its individuality but to profit from China's economic take-off and position itself as the hub for the coun-

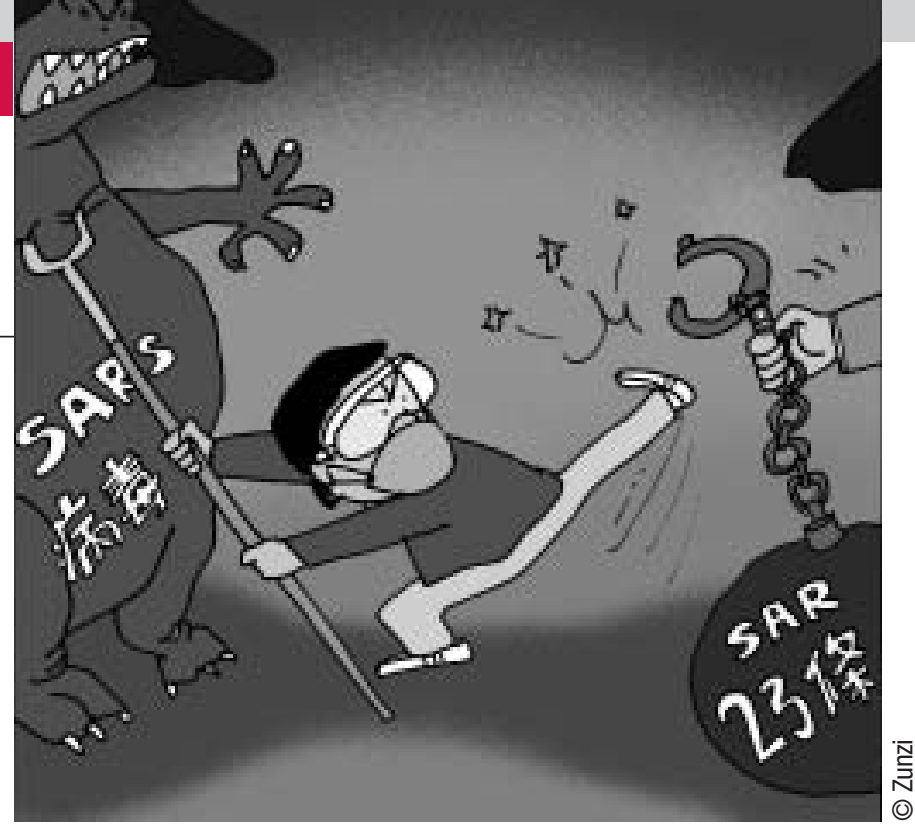

try's financial services.

Well understood interests

\section{In Hong Kong's case, profiting from new stock exchange developments...}

Although the creation of channels for China-incorporated companies to list their shares directly or indirectly in Hong Kong dates from $1992^{(10)}$, the Hong Kong Stock Exchange (HKSE), up to the time of the transfer of sovereignty, dealt mainly with British and Hong Kong interests. Thus, in 1997, of the 15 largest enterprises listed in Hong Kong, only one was Chinese and less than 10\% of Hong Kong's market capitalisation was in Chinese firms. The real estate, construction and public works sectors were strongly represented. Ten years after the handover, the scene has changed considerably: half of Hong Kong's stock exchange market capitalisation is by Chinese enterprises ${ }^{(I I)}$. Of the 15 largest firms listed in Hong Kong in December 2006, six were from mainland China ${ }^{(12)}$. The banking and energy sectors are now heavily represented.

In Hong Kong, the financial services sector is the second most important in GDP terms ${ }^{(1)}$, and is a driving force in the economy. The entry of Chinese firms into the stock market has thus been a godsend for the SAR. Of the ten largest initial public offerings (IPO) ever recorded in Hong Kong,

7. An enlightening description of the issues involved in the sovereignty negotiations can be found in Michel Bonin, Les zigzags de Pékin, op. cit., pp. 15-35

8. Wenhui Zhu, "Toward an Integrating Market: The Future of Hong Kong's Economy And Its Interaction With The Chinese Mainland", CNAPS Working Paper Series, 2005 available at http://www.brook.edu/fp/cnaps/papers/zhu20051017.htm.

9. CEPA or the Close Economic Partnership Arrangement, was signed in June 2003 and came into force on 1 January 2004. Between 2003 and 2005 three sets of measures were added to enhance even further the effects of the arrangements.

10. The listing of Chinese enterprises in Hong Kong takes two forms: $\mathrm{H}$ shares, reserved for Chinese companies, and Red Chips, reserved for Chinese companies with subsidiaries in Hong Kong through which they enter the stock market.

11. $25.4 \%$ in the form of $\mathrm{H}$ shares, and $22.3 \%$ as Red Chips

12. China Mobile, Industrial and Commercial Bank, Bank of China (H shares), CNOOC, Petrochina, Bank of China Ltd (red chip)

13. The first is the trade and logistics sector which accounts for $23 \%$ of GDP. 
Insert 1: "One country, two systems": preserving Hong Kong's legal framework ...

To preserve the framework favourable to business established by the British administration, the Basic Law was adopted in 1997. It was based on the joint declaration signed by the United Kingdom and the PRC in $1984^{(1)}$. Hong Kong and the business community were assured that 'the socialist system and socialist policies will not be in force in the Special Administrative Region, which will maintain unchanged the previous capitalist system and way of life of the Territory for fifty years to come'. Hong Kong remains a fiscal, customs, and monetary territory which is completely independent from mainland China ${ }^{(2)}$. The Territory maintains its currency, the HKD, which is freely convertible ${ }^{(3)}$, and complete freedom of movement of capital ${ }^{(4)}$. Complementing these principles, the Central Bank of China (PBOC) solemnly undertook to maintain 'two mutually independent currencies, monetary systems and monetary authorities', and not to make use of the Hong Kong's currency reserves, in any form ${ }^{(5)}$, and to prohibit fiscal transfers.

1. Joint declaration of the government of the United Kingdom of Great Britain and Northern Ireland and the Government of the People's Republic of China on the question of Hong Kong, December 19, 1984.

2. Article 109

3. Article 112

4. Article 113

5. On the other hand, contrary to the strict principle of independence, the PBOC stands ready to support the Hong Kong currency, if necessary, at the request of the HKMA.

ten were Chinese. The scale factor exerted by China has consequently also made itself felt in financial terms: the amount of capital raised on the exchange by Chinese enterprises has beaten all records. Eclipsing China Construction Bank in 2005, with US\$9.1 billion, the listing on the HKSE of Industrial and Commercial Bank led in 2006 to the raising of US\$16 billion, thus effecting the largest stock exchange IPO ever seen in the world. Bank of China, which also entered the HKSE, raised US\$11.1 billion, while Merchant Bank, a business of more modest size, raised US $\$ 2.6$ billion

Thus, from a financial centre of regional significance, Hong Kong grew in 2006 to being fourth in world ranking in terms of funds raised, behind New York, Euronext and London,
Table 1. The 10 largest entries on the Hong Kong stock exchange since 1993

\begin{tabular}{|c|c|c|c|}
\hline Rank & Enterprises & $\begin{array}{c}\text { Capital } \\
\text { raised } \\
\text { (billions } \\
\text { of HKD) } \\
\end{array}$ & $\begin{array}{l}\text { Date of } \\
\text { listing on the } \\
\text { Exchange }\end{array}$ \\
\hline 1. & $\begin{array}{l}\text { Industrial and } \\
\text { Commercial } \\
\text { Bank of China } \\
\text { Ltd. }\end{array}$ & 125.0 & $27 / 10 / 2006$ \\
\hline 2. & $\begin{array}{l}\text { Bank of China } \\
\text { Ltd. }\end{array}$ & 86.7 & $01 / 06 / 2006$ \\
\hline 3. & $\begin{array}{l}\text { China } \\
\text { Construction } \\
\text { Bank } \\
\text { Corporation }\end{array}$ & 71.6 & $27 / 10 / 2005$ \\
\hline 4. & $\begin{array}{l}\text { China Unicom } \\
\text { Ltd. }\end{array}$ & 43.6 & $22 / 06 / 2000$ \\
\hline 5. & $\begin{array}{l}\text { China Mobile } \\
\text { Ltd. }\end{array}$ & 32.7 & 23/10/1997 \\
\hline 6. & $\begin{array}{l}\text { China Life } \\
\text { Insurance Co. } \\
\text { Ltd }\end{array}$ & 26.7 & $18 / 12 / 2003$ \\
\hline 7. & $\begin{array}{l}\text { China } \\
\text { Petroleum \& } \\
\text { Chemical } \\
\text { Corporation }\end{array}$ & 26.7 & $19 / 10 / 2000$ \\
\hline 8. & $\begin{array}{l}\text { China Shenhua } \\
\text { Energy Co. Ltd }\end{array}$ & 25.5 & $15 / 06 / 2005$ \\
\hline 9. & $\begin{array}{l}\text { PetroChina Co. } \\
\text { Ltd. }\end{array}$ & 22.3 & $07 / 04 / 2000$ \\
\hline 10. & $\begin{array}{l}\text { China } \\
\text { Merchants Bank } \\
\text { Co. Ltd }\end{array}$ & 20.7 & $22 / 09 / 2006$ \\
\hline
\end{tabular}

Source: Data of the Hong Kong Exchange

reaching US\$67 billion ${ }^{(14)}$.

\section{... and conquering the chinese banking market}

Moreover, although regarded in the PRC as foreign credit

14. Source: World Exchange Federation data, December 2006 
Table 2. The leading 10 foreign banking institutions most widely represented in China

\begin{tabular}{|c|c|c|}
\hline Institution & $\begin{array}{l}\text { Origin of the } \\
\text { shareholding }\end{array}$ & $\begin{array}{l}\text { Number of } \\
\text { branches/ } \\
\text { representative } \\
\text { offices in } \\
\text { China }\end{array}$ \\
\hline HSBC & $\begin{array}{l}\text { United } \\
\text { Kingdom }\end{array}$ & 27 \\
\hline Bank of East Asia & Hong Kong & 27 \\
\hline $\begin{array}{l}\text { Standard } \\
\text { Chartered }\end{array}$ & $\begin{array}{l}\text { United } \\
\text { Kingdom* }\end{array}$ & 20 \\
\hline Citibank & United States* & 15 \\
\hline Hang Seng Bank & Hong Kong & 15 \\
\hline Sumitomo Mitsui & Japan & 9 \\
\hline $\begin{array}{l}\text { Bank of Tokyo- } \\
\text { Mitsubishi }\end{array}$ & Japan & 9 \\
\hline BNP Paribas & France* & 7 \\
\hline $\begin{array}{l}\text { United Overseas } \\
\text { Bank }\end{array}$ & Singapore & 7 \\
\hline $\mathrm{BOCHK}$ & China* & 7 \\
\hline
\end{tabular}

Source: Report Moody's Investors Service ${ }^{6}$

* indicates a significant presence in Hong Kong.

institutions, Hong Kong banks receive preferential treatment under the CEPA which reduces-though it does not remove-the extremely restrictive conditions governing access to the Chinese banking system by foreign investors ${ }^{(15)}$. Through businesses located in mainland China, Hong Kong banks also enjoy privileged treatment for insurance products and services. Thus, of the ten foreign enterprises most firmly established in China at the end of 2006, half are Hong Kong-based credit institutions or credit institutions with strong historical links with Hong Kong. Several credit institutions, either Hong Kong-owned or with a presence in Hong Kong, have also taken out major strategic interests in Chinese banks, in particular HSBC which owns $19.9 \%$ of the Bank of Communications, $8 \%$ of the Bank of Shanghai and a 16\% indirect interest in Industrial Bank, via its subsidiary Hang Seng Bank.

The CEPA has undeniably played a role in the favourable positioning of Hong Kong banks in China, even if the number of establishments benefiting from the arrangements might seem relatively small ${ }^{(16)}$ : at the end of December 2006, only eight Hong Kong-based banks had become eligible under the CEPA ${ }^{(17)}$, which does not seem many given the 200 credit institutions in Hong Kong. An equally important factor for Hong Kong firms is their understanding of the market near their border and the previous well-established relationships with Chinese authorities. In sum, the importance of the CEPA seems to spring as much from the favourable policy signals the PRC sends to the SAR as from the granting of decisive competitive advantages to Hong Kong banks.

\section{For China, financing its economy...}

In 2000 the HKSE took over from mainland exchanges, assuming principal responsibility for the issue of Chinese stocks, enabling the emergence of a derivative market related to Chinese stocks, and finally realising the IPO of the major Chinese banks, a crucial step in bank reform.

One should therefore see the stock exchange developments of 2005 and 2006 as a logical extension of the replacement role that the Hong Kong exchange has played since 2000. Given the dysfunctional state of exchanges in mainland China, Hong Kong had only to occupy a position that had already been left vacant. Indeed, practices in Shanghai and Shenzhen until the 2006 reform were characterised by fraudulent dealings, non-existent accounting transparency, shares mostly non-tradable and the issue of stocks without prior regulatory checks. In the expectation of reform, demand for stocks therefore became paralysed. This explains why the stock exchange indicators between 2001 and 2005 in no way reflected the real rate of growth in China: while the country's GDP doubled over this period, stock exchange indicators and the capitalisation of Shanghai and Shenzhen fell by half ${ }^{(18)}$. As a source of finance for the Chinese economy issue of stocks therefore played a very small role.

In this context, Hong Kong seems a comfortable alternative for Chinese enterprises seeking to raise capital. This financial hub, which has maintained a regulatory framework conforming to international standards, therefore listed stocks

15. For Hong Kong banks, the CEPA has lowered the credit threshold for a foreign bank wishing to establish itself in China from US\$20 billion to US\$6 billion. Hong Kong banks can offer services in renminbi and in foreign currency transactions two years after opening a branch compared with the three currently required for foreign banks. While China's regulations require foreign banks to show a profit in each branch to gain a licence to operate in renminbi, the CEPA allows an overall calculation of profits for all branches.

16. In the absence of a list of the names of credit institutions benefiting from the CEPA, a precise impact study is difficult to undertake.

17. Which includes three medium-sized Hong Kong banks, which claimed to benefit from it, and, more surprisingly, two subsidiaries of Chinese banks, CITIC and Bank of China.

18. Anne Laure Delatte and Maud Savary-Mornet, "Hong Kong, plate-forme financière de la Chine continentale", Revue Banque, $n^{\circ}$ 688, 2007. 
Table 3. Total and negotiable capitalisation in mainland China and capitalisation of Chinese enterprises in Hong Kong.

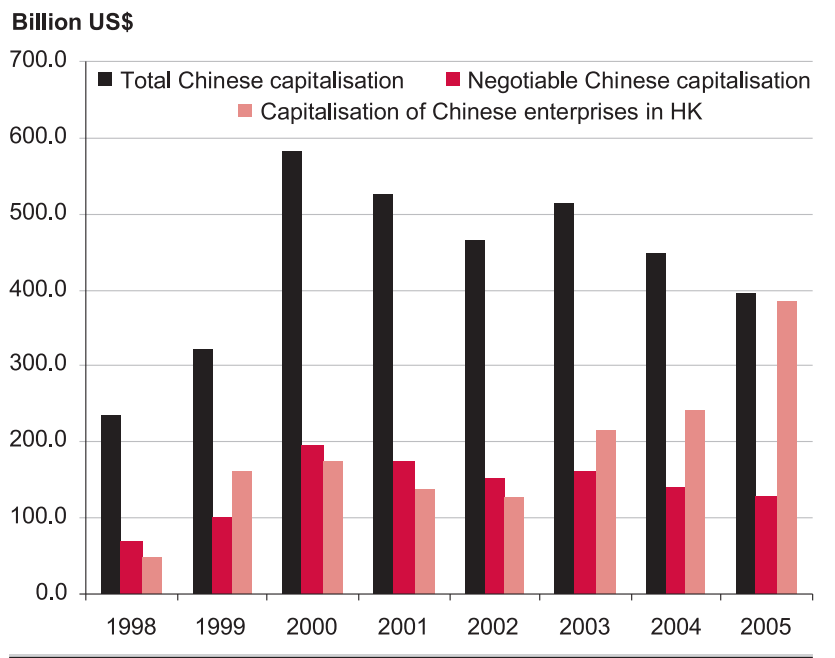

Sources: Chinese Statistical Yearbook and Hong Kong Exchange statistics (HKex).

from Chinese enterprises which appeared solidly based. Figure 3 summarises the increased importance Hong Kong has assumed in financing Chinese enterprises. In total, in 2004, stock exchange capitalisation in Hong Kong for Chinese businesses rose to US $\$ 240$ billion, that is, almost double the capitalisation in play on mainland exchanges (US\$140 billion). In 2005, this ratio again increased: the value of stocks of Chinese enterprises in Hong Kong was three times greater than in mainland China (US\$385 billion).

In this context, it is worth taking a closer look at 2003, which was a turning-point in the utilisation of Hong Kong's financial capability by Chinese enterprises. This development is linked to the strategy of mainland authorities to place Hong Kong at the heart of the reform of China's state enterprises, especially those in the banking sector. The consolidation of their assets through the inclusion of foreign strategic investors was made possible by the record IPO detailed above: ICBC, Bank of China, China Construction Bank, China Merchant Bank.

In short, China has provided itself with a sophisticated financial centre on its border, wholly dedicated to its own economic development. Hong Kong also represents a testing ground for its future reforms.

\section{... experimenting and gaining regulatory knowledge...}

Over the decade, the Hong Kong banking sector has con- tributed only very moderately to the financing of the Chinese economy. In March 2007, outstanding loans by the Hong Kong banking sector to its mainland Chinese counterparts was low compared with the funds raised by Chinese enterprises on the HKSE in 2007 (HKD 384 billion), and this was even a $5 \%$ reduction compared with $1997^{(19)}$. The regulatory and prudential restrictions on loans to Chinese establishments by foreign banks, as well as the collapse of GITIC ${ }^{(20)}$ in 1999, also probably acted over the decade as brakes on the expansion of the Hong Kong banking sector vis-à-vis Chinese counterparts.

All the same, one should not underestimate the interaction between the Hong Kong banking sector and the Chinese economy. Indeed, the SAR enabled Chinese banks situated in Hong Kong to acquaint themselves, under relatively favourable conditions, with the rules of the game in a liberalised banking sector. It also allowed them to adapt to international prudential standards.

The subsidiaries of Chinese banks in Hong Kong ${ }^{(21)}$ were, over the course of the decade, able to gain experience of the operational rules of a liberal system, under conditions tempered by the geographic and cultural proximity of the Hong Kong market and, in any case, less difficult than those applying in more distant markets. This apprenticeship was also made easier by the long-established cartelised nature of the Hong Kong banking market, which has only been truly liberalised in relatively recent times (from 1999 to 2001) ${ }^{(22)}$.

For Chinese banks, Hong Kong has also played the role of a training school in risk management. The SAR is in fact a pioneer in Asia of the most advanced international banking stan-

19. Looking at total financial flows, the PRC even seems to have been the only geographic zone with which the Hong Kong banking system is in a net debit position in December 2006, to the tune of HKD 130 billion, unlike the United Kingdom (with a net credit position of HKD 965 billion) or the United States (net credit position of HKD 228 billion).

20. The collapse of the Guangdong International Trust and Investment Corporation in October 1998 left a total estimated debt of HKD 33 billion, spread across 120 credit institutions, mainly in Hong Kong. Following this collapse, credits in Hong Kong-based banks for Chinese entities fell from 4.5\% of total credits in September 1998 to 3.4\% in December 1999 .

21. From 35 in 1997, their number fell to 16 in 2006 following various mergers and acquisitions, in particular the merger in 2001 of the ten banks of the Bank of China consortium into a single entity.

22. The Hong Kong authorities have introduced reforms to modify the operation of the Hong Kong banking system, which has been seen as too oligopolistic. Several measures have been adopted to foster competition among credit institutions: deregulation of interest rates, in 2001; facilitation of market access by foreign banks from 1999; and encouragement for mergers-acquisitions among institutions.

23. Hong Kong began to apply the Cooke ratio in 1989, well in advance of the Basel date which provided for a start date at the end of 1992. Monitoring of market risk began in 1997, shortly after the recommendations of the Basel committee in January 1996. For Basel 2: the start date is in 2007 (simple forms) and in 2008 (more complex forms) while Chinese authorities have set no start no implementation date for their banking system. 


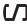

dards, whether this be for market risk or for international minimum requirements regarding credit institutions' own funds ${ }^{(23)}$. Chinese banks in Hong Kong are of course subject to these standards, which have allowed them to master risk management more rapidly than if they were closeted in their home market ${ }^{(24)}$.

\section{... and testing - modestly - the external convertibility of the renminbi}

Finally, since 2004, Hong Kong banks have been able to offer banking services in renminbi to their individual customers only: deposits, currency exchanges and transfers in renminbi, and credit/debit cards in renminbi, which can be used in the PRC. Like retail businesses, the banks can also accept credit cards issued by Chinese continental banks, as well as renminbi in cash. For the present these measures are only available for individuals, not for enterprises; which explains why the use of such services has remained very marginal (for example, deposits in renminbi only represent $0.5 \%$ of total deposits in Hong Kong banks). The extension of these measures to enterprises, in particular authority to pay for import/ export activities in renminbi, has been announced-though without any specific timetable-and this will be a crucial step towards the free convertibility of the renminbi, once more reaffirming Hong Kong's status as an arena for experimentation and learning.

In sum, the contribution of the HKSE to Chinese reforms has been obvious in the many listings by Chinese enterprises over the decade; in addition, Chinese banks in Hong Kong have been able to adjust to the operational rules of an international banking centre. This specific state of affairs-a developing economy which has a sophisticated financial market available on its doorstep-has been a great asset for China, which until now has been shut away on its own territory from short-term foreign capital. All the same, joining the WTO could well change the current arrangements and place Hong Kong is a less favourable situation where it will need to deal with new competitors. On the other hand, this strategy brings new risks, which are discussed below.

\section{Towards a new equilibrium}

\section{The WTO agreements reduce the regula- tory advantages benefiting banks based in Hong Kong}

In the context of its admission to the WTO in 2001, China undertook to open up its banking sector from 11 December
2006. Although the extent of liberalisation of the Chinese market is still limited ${ }^{(25)}$, these new arrangements automatically reduce the comparative advantages which the CEPA conferred on Hong Kong banks.

All the same, as explained above, the CEPA alone does not explain the advantage that Hong Kong banks had already acquired. The latter remain in a favourable position to dominate the Chinese banking market by virtue of their closeness in cultural terms accentuated by the increasing involvement of Hong Kong in the Pearl River Delta and the wellestablished nature of policies relating to China. Moreover, the strategy developed by foreign banks until then for involvement in Chinese banks seemed less attractive since Chinese authorities may have confirmed their intention of not lifting the ceiling for capital participation of foreign banks in the capital of a Chinese bank above 20\%. Also, the establishment of a network of ad hoc subsidiaries in China may seem to be the best option for foreign banks, as in this process banks located in Hong Kong may enjoy a relative advantage given their proximity to Chinese markets and their well established links with Chinese authorities. Those foreign banks seeking to establish a network of subsidiaries in China whose discussions with Chinese regulators have reached the most advanced stage are, moreover, principally those which are already established in Hong Kong ${ }^{(26)}$.

\section{Increased competition from shanghai and major international centres leads Hong Kong to further adjust its position in rela- tion to China}

Far from simply living off the benefits available to it by virtue

24. There remains the question, which we have not discussed here for lack of space, of skills transfer from Hong Kong subsidiaries to parent institutions in mainland China.

25. China undertook to remove the non-prudential measures applicable until then to foreign banks wishing to enter the Chinese market; however, it did not undertake to remove the prudential measures, a situation which enables it, like most countries in the area, moreover, to continue to exercise regulatory measures to protect its banking market from foreign participants. Despite the formal liberalisation of the banking system within the framework of the WTO, the process of obtaining a banking licence in China remains complex and costly. Foreign players are strongly encouraged to work through subsidiaries, a method which is very costly in terms of capital (1 billion yuan for a subsidiary, 200 million yuan for a branch). In addition there is a profitability test which applies to the subsidiary of the foreign bank if it is to obtain a renminbi licence, and a requirement to show that the bank has been in operation for more than three years and has been profitable for at least two consecutive years. Foreign banks choosing to establish themselves in the form of branches can only accept deposits for more than 1 million yuan and cannot issue credit cards. In addition, participation in a Chinese bank by a foreign entity is limited to $20 \%$ of capital for individual participation and $25 \%$ for a group of investors.

26. As well as the American Citigroup there is HSBC, Standard Chartered and the Bank of East Asia, a Hong Kong bank: The Standard, 17 April 2007. 
of its privileged position in arrangements for the reform of Chinese banks and large state enterprises, the Hong Kong stock market needs to deal with increasing competition. To start with, there is competition from mainland China. For the first time, in mid-April 2007, total stock exchange capitalisation in Shanghai and Shenzhen has exceeded that of Hong Kong. Reform of mainland financial markets resulted in the resumption of IPOs on the Shanghai stock exchange, successfully initiated by the double listing of ICBC in October 2006. The leading Chinese credit institution in fact enjoyed the largest IPOs in terms of funds raised-21.9 billion yuan raised simultaneously in Hong Kong and Shanghai. At the same time, Chinese authorities seem to want, perhaps temporarily, to favour mainland markets. Although no official announcement has been made, the CRSC, which is required to approve all requests of IPOs of Chinese enterprises on the stock exchange, is thought to have been encouraging enterprises since the beginning of 2007 to give preference to funds raised on the mainland markets (in the form of A shares), at the expense of those from the Hong Kong market ( $\mathrm{H}$ shares). Thus, in the coming weeks, it is expected that there will be several IPOs on the Shanghai market of large Chinese enterprises already listed in Hong Kong (China Mobile, Petrochina, Chalco, Bank of Communications ${ }^{(27)}$.) On the other hand, as the HKSE authorities are stressing ${ }^{(28)}$. Chinese firms are, as part of their internationalisation strategy, now looking for funds in other markets-in Europe, America ${ }^{(29)}$ or Asia.

This increasing competition is, as one would expect, leading Hong Kong to position itself in ways best adapted to the needs of the Chinese economy. This strategy emerges clearly in several documents ${ }^{(30)}$ developed by Hong Kong authorities following the eleventh plan, which forms an important element of the necessary reforms of the financial sector in the PRC. The strategy developed by the Hong Kong authorities is formulated around two principal ideas. On the one hand, the aim is to position Hong Kong's financial centre as the key agent in the reform process in the Chinese financial sector. Hong Kong's financial centre would put its expertise and infrastructure at the service of the gradual, progressive opening of the Chinese capital account. On the other hand, Hong Kong's aim would be to strengthen its institutional links with mainland authorities by means of "complementary, co-operative and interactive" relations ${ }^{(31)}$. Here we can plainly see the distance covered since the transfer of sovereignty ...

Accordingly, Hong Kong authorities are promoting a number of projects to their Chinese counterparts. The first plank of development concerns arrangements allowing Chinese institutional investors to invest a portion of Chinese savings abroad. The QDII ${ }^{(32)}$ could be extended to Hong Kong share markets, either directly, or through funds. Within the context of a partial opening of the Chinese capital account, the wealthiest individual Chinese investors would be permitted to make foreign currency investments in Hong Kong on an experimental basis limited to individuals with funds in excess of 1 million yuan. The second plank is the extension of the off-shore renminbi market, begun in 2003 on an experimental basis, which could be enlarged by developing an organised market for contracts, futures and options for the renminbi ${ }^{(33)}$. Other measures would build on the sophisticated nature of Hong Kong as a centre which could become an organised market for debenture listings in renminbi. This final measure seems to be the one that has reached the most advanced stage because the Hong Kong authorities have announced several times that the arrangements would be in place by the end of 2007. Chinese financial institutions could thus issue bonds denominated in renminbi, which would be listed and traded in Hong Kong.

\section{The ambiguities of the Hong Kong/China financial integration}

\section{Vulnerability to fluctuations in China}

Hong Kong today is, admittedly, in a favourable situation which allows it to derive great benefit from the burgeoning Chinese economy. All the same, this situation is not without its problems: China's increasing involvement in Hong Kong's financial activities increases the latter's risk levels. Thus, today, the Hang Seng index is sensitive to develop-

27. Nisha Gopalan, "China pushes for listings", Wall Street Journal, 18 April 2007.

28. Presentation by Paul Chow, HK ex Chief Executive, entitled "The Evolving Role of Hong Kong as a Securities Market for the Mainland", at the HKU Foundation annual meeting cum HKU Luncheon Talk, 12 March 2007; available at HKex website http://www.hkex.com.hk/index.htm.

29. Certain Chinese enterprises are moreover already listed on other international exchanges, mainly in New York and London.

30. See Li David (Ed), "Report of the Focus Group on Financial Services", January 2007, available at http://www.info.gov.hk/info/econ_summit/eng/pdf/fs.pdf. The Focus Group on Financial Services is a working group of representatives of the financial industry and the Hong Kong government, chaired by David Li.

31. Li David (Ed), "Report of the Focus Group on Financial Services", op. cit. p. 1.

32. Qualified Domestic Institutional Investors, financial institutions incorporated in mainland China authorised to acquire shares on foreign exchanges.

33. Hong Kong already has an OTC market for renminbi NDF (non deliverable futures) for institutional investors 
(2)

ments in China: for example, on 28 February 2007, the 10\% fall in the Shanghai index led to a fall of 3\% in the Hang Seng. Similarly, following the announcement by the People's Bank of China (PBOC), China's central bank, on 29 April 2007 of a tightening of monetary conditions in China, the overall Hong Kong index fell 1\% in a day. Volatility of the mainland's stock exchanges is likely to increase still further in 2007: the Shanghai stock exchange index has gone up 220\% since the first semester of 2006 without the same tendency showing up in profits; China's high rate of savings and the scarcity of investment opportunities in China combine to make the stock exchange highly attractive, to the point of triggering highly speculative investment behaviours. The very strong demand has pushed stock exchange indexes to levels that some consider unsustainable. The rare foreign institutional investors in China maintain very cashed-up in order to enable them to withdraw quickly in case of a turnaround. Very short-term investments by the institutional sector mean that the indexes are susceptible to sudden, major changes. Many observers believe that the growth of mainland indexes cannot continue at this rate ${ }^{(34)}$. The question now is to know whether Chinese exchanges are in for a hard or a soft landing. What will the consequences of the landing be for Hong Kong? How will Hong Kong's international investors react? As already said, the Hong Kong economy is heavily exposed to the financial sector. The crisis in 1997 showed that a fall in the Hang Seng index, far from being limited to the stock exchange market, had systemic consequences for the rest of the economy.

Moreover, the risks are not restricted to Hong Kong alone. For China, this model has its limitations, as we will now show.

\section{Hong Kong... in the Chinese balance of payments}

Hong Kong is, it is true, an undeniable asset for China's economic development. A major feature of Hong Kong is that it is completely open to movements of international capital. Thus, in 2004 and $2005^{(35)}$, foreign investors contributed $36 \%$ of transactions on the share market, and $23 \%$ on the market for derivatives. Foreign investors in share trading are based mainly in the United States (29\%), the United Kingdom (25\%), and the rest of Europe (22\%), the Asian sector being relatively weak (13\%). In other words, since 2000, and not only in 2005 and 2006, China has been quite openly exposed to foreign stock market capital through the intermediary of Hong Kong.

\section{Insert 2: What role did funds raised in Hong Kong play in the record entries?}

Until 2003, funds raised in Hong Kong were for the most part repatriated to China and converted into RMB in order to finance investments on Chinese territory. However, the success of China's investments overseas since 2003, about which a lot has been written, and which has been greeted with varying degrees of concern in the developed world, might well have been financed by capital raised in Hong Kong. Since the purpose to which funds raised on the exchange are put does not need to be declared once the listing on the exchange has been effected, there is no systematic way of identifying it. The result has been arrived at by carefully examining the annual reports of the leading 15 Chinese enterprises listed in Hong Kong and also noting the statements of investments and acquisitions by these enterprises in the economic and financial press. If there is a short delay between listing and investment or acquisition, it has been assumed there is a causal link.

Thus, China Construction Bank, which had raised funds in November 2005, announced the acquisition of Bank of America Asia ${ }^{(1)}$ for USD 1.24 billion in 2006. Similarly, ICBC (Industrial and Commercial Bank of China), whose listing in Hong Kong dates from November 2006, acquired $90 \%$ of the holdings of the Indonesian bank Halim in January 2007. In July 2006, six months after its fund raising, Bank of China, announced the acquisition of all the holdings of Singapore Aircraft for US\$ 965 million. And on August 23, 2006, PetroChina acquired $67 \%$ of the capital issued by PetroKazakhstan.

1. A franchise in Hong Kong and Macao of Bank of America Corporation

But there is a strong contradiction in a policy that maintains a closed capital account, associated with arrangements for controlling capital flows, while at the same time calling on international savings from beyond its borders. China today depends on the stability of its currency. This is in fact one

34. For the risk of a speculative bubble on mainland markets, see Henry Ho and Louis Shan, "Where are China shares going?", UBS report, Hong Kong, 7 May 2007.

35. "The international dimension of HKex Securities Market-investors and brokers", The Exchange, Hong Kong Exchange, N. July, 2006. 
of the pillars of its growth as it depends in large measure on the export sector. Too much volatility would mean great uncertainty. This is, in any case, the implicit justification for the authorities' attachment to its currency arrangements ${ }^{(36)}$. Now, it is because capital is not free to move in and out of the country that the exchange rate of the renminbi is able to remain linked to fluctuations of the dollar while at the same time offering an interest rate higher than the United States. But the PRC is a victim of its economic success. The record accumulation of foreign currency reserves in the $\mathrm{PBOC}$ is a reflection of this. Until now the reserves have been essentially linked to the current account surplus-China's commercial success. But since 2003, capital has been there in abundance, despite the controls ${ }^{(37)}$ : because there are exceptions, and faults in the system, but also because foreigners can buy shares on the stock exchange in listed Chinese enterprises ... from Hong Kong. Thus, the PRC is playing an ambiguous game by limiting financial dealings between Chinese and foreigners within its borders yet at the same time calling on international savings via Hong Kong.

This situation could now be working against China. Indeed, the funds raised by new entrants on the exchange outside China further accentuate the currency exchange problem. Thus the listing of Chinese banks on foreign exchanges between 2005 and 2006 represented a fund raising of US\$90 billion in all, US\$50 billion of which came from Hong Kong. The repatriation of such sums, and their conversion, further increase the demand for renminbi, thus posing a significant problem for the authorities in charge of currency exchange (the State Administration of Foreign Exchange (SAFE) and the PBOC). The latter have certainly tried discreetly to limit the repatriation of these funds. Thus, it is likely that the foreign acquisitions described in Insert 2 received active support if not outright encouragement by the authorities. But the presence of assets in US dollars weighs more and more heavily on the balance sheets. The latter depreciate by $5 \%$ per annum on average compared with the renminbi, causing proportional exchange rate losses. Thus, Guo Shuqing, the CEO of China Construction Bank, an enterprise whose IPO on the HKSE dates from 2005, complained publicly in 2006 about being "forced" (implicitly by the SAFE) to maintain these funds in US dollars while they were depreciating, causing exchange losses of the order of 300 million US dollars. The appreciation of the renminbi relative to the US dollar calls for a rational reallocation of US dollars assets in renminbi. This finally happened at the beginning of 2007 as Wu Xiaoling, vice-governor of the PBOC, eventually confirmed in April 2007: the increase between the first trimesters of 2006 and 2007 of 37\% of exchange reserves (sic), which pushed China into the number one position in the world, is thought to reflect in part the trading surplus but also the fact that Chinese enterprises, motivated by anticipated appreciations of the renminbi, repatriated funds raised on foreign exchanges, despite the restrictions. Thus Hong Kong becomes embroiled in the difficult question of the Chinese exchange rate regime ${ }^{(38)}$.

\section{Conclusion}

The long-standing economic relations between Hong Kong and the PRC have intensified since the handover at a pace few foresaw. Alongside the increasing economic links, the financial sector has been an important driver of integration. This intensification has taken place in successive stages: after a dormant period designed to preserve the balance provided for in the agreements reached at the time of the transfer of sovereignty, the CEPA in 2003 was the signal for a policy of preferential treatment for Hong Kong. Banks located in Hong Kong found they were beneficiaries of preferential policies for access to the Chinese market. But the most spectacular step was taken in 2003 in the stock exchange area. Hong Kong was given a privileged position in the stock exchange IPOs of the large state enterprises and the banks. This recourse to Hong Kong served a dual purpose: it validated the reform process undertaken by the Chinese authorities, especially in the banking sector, and it provided access to the only Chinese stock exchange attracting foreign savings. For Hong Kong, the record funds raised on its exchange were a godsend for its economy. All the same, Hong Kong's financial integration with China is not without its risks because China is an emerging financial market which is both speculative and volatile. Without calling into question this dual purpose, we may wonder whether it would be worthwhile considering other strategies that would put Hong Kong in a position that is less dependent on economic and financial fluctuations in China-by acting, for example, as a financial centre for Asia as a whole, in the manner of Singapore. $\bullet$

\section{- Translated by Peter Brown}

36. Despite the authorised appreciation of the renminbi since July 2005, the currency exchange regime can still be regarded as a controlled system.

37. On this topic see for example, Anne Laure Delatte "Is the Chinese Current Exchange Rate Regime Sustainable?" China Perspectives, vol. 67, 2006, pp. 11-20.

38. On this topic see Michael Goujon and Samuel Guerineau, "The Modification of the Chinese Exchange Rate Policy", China Perspectives, vol. 64, 2006, pp. 34-44. 